\title{
ISOLASI JAMUR ENDOFIT DAUN BELUNTAS (PLUCHEA INDICA (L.) LESS)
}

\author{
Jessie Elviasari, Rolan Rusli, Adam M. Ramadhan \\ Laboratorium Penelitian dan Pengembangan "FARMAKA TROPIS" Fakultas Farmasi \\ Universitas Mulawarman, Samarinda, Kalimantan Timur \\ email: jessie_viasari@yahoo.com
}

\begin{abstract}
ABSTRAK
Tanaman memiliki 1 sampai 4 jenis jamur yang hidup berasosiasi dengan tumbuhan sebagai jamur endofit. Jamur endofit merupakan jamur yang tumbuh pada bagian tanaman yaitu terdapat pada bagian jaringan akar, batang, dan daun. Tujuan penelitian ini adalah untuk mengisolasi dan mengetahui ciri secara makroskopik dan mikroskopik jamur endofit yang terdapat pada daun beluntas. Penelitian dilakukan dengan mengisolasi jamur endofit dari daun beluntas menggunakan medium Potato Dextrose Agar Chloramphenicol (PDAC), kemudian dilakukan pemurnian pada jamur endofit serta mengkarakterisasi isolat jamur endofit. Hasil penelitian adalah diperoleh tiga isolate jamur endofit yang tumbuh pada daun beluntas, yaitu isolat jamur endofit hitam 1, isolat jamur endofit hitam 2, dan isolat jamur endofit putih.
\end{abstract}

Kata Kunci: Jamur endofit, isolasi, beluntas (Pluchea indica (L.) Less.)

\section{PENDAHULUAN}

Slogan "back to nature" atau kembali ke alam, kerena memiliki kandungan metabolit sekunder atau senyawa aktif, yang berakibat pada semakin berkurangnya sumber daya alam tanaman tersebut disebabkan adanya eksploitasi bagian tanaman sebagai tanaman obat yang terus meningkat. Salah satu langkah mengurangi eksploitasi adalah dengan mengisolasi jamur endofit pada bagian tanaman tersebut, karena dapat memproduksi senyawa aktif seperti pada tanaman tersebut.

Strobel dan Daisy (2003) memperkirakan paling tidak ada 1 sampai 4 jenis jamur yang hidup berasosiasi dengan tumbuhan sebagai jamur endofit yang bersifat culturable (bisa ditumbuhkan pada kondisi artifisial). Mikroba endofit merupakan mikroorganisme yang tumbuh dalam jaringan tumbuhan. Mikrobia endofit ini memiliki potensi yang besar dalam pencarian sumber-sumber obat baru. Hal ini karena mikroba merupakan suatu organisme yang mudah untuk ditumbuhkan, memiliki siklus hidup yang pendek, dan dapat menghasilkan jumlah senyawa bioaktif dalam jumlah besar dengan metode fermentasi (Agusta, A., 2009).

Dengan demikian potensi ini dapat dikembangkan dengan isolasi jamur endofit, khusunya pada jaringan daun beluntas karena daun beluntas memiliki senyaawa aktif yang dapat berkhasiat dalam mengatasi gangguan pencernaan, skrofuloderma, stomakik, diaforetik, antipiretik dan rematik. Oleh karena itu, dalam penelitian ini dilakukan isolasi dan karakterisasi jamur endofit yang terdapat pada daun beluntas.

\section{METODE PENELITIAN}

\section{Bahan}

Bahan yang diteliti adalah daun beluntas (Pluchea indica (L.) Less.). Untuk sterilisasi permukaan daun beluntas digunakan alkohol $70 \%$ dan $\mathrm{NaOCl} 5,25 \%$. Medium yang digunakan adalah Potato Dextrose Agarl PDA (Merck, 1.10130.0500) yang ditambahkan kloramfenikol selanjutnya 
disebut Potato Dextrose Agar Cholramphenicol (PDAC). Bahan yang digunakan untuk uji mikroskopik yaitu gliserin, kertas saring dan methylene blue.

\section{Peralatan}

Peralatan yang digunakan dalam penelitian ini adalah timbangan analitik, autoklaf, inkubator, cawan petri, erlenmeyer, gelas kimia, spoit injeksi, hot plate, bisturi, Laminar Air Flow, mikroskop kamera dan alat penunjang lainnya.

\section{Prosedur}

a. Isolasi Jamur Endofit

Teknik isolasi jamur endofit ini dilakukan dengan metode tanam langsung. Selama pengerjaan isolasi dilakukan di dalam LAF (Laminar Air Flow) dalam kondisi steril. Sampel daun beluntas dicuci dengan air mengalir terlebih dahulu. Selanjutnya dilakukan sterilisasi permukaan sampel dengan cara direndaman sampel dalam alkohol $70 \%$ selama 1 menit, kemudian direndam dalam $\mathrm{NaOCl}$ 5,25\% selama 3 menit dan direndam kembali dalam alkohol $70 \%$ selama 30 detik. Jaringan daun dibuka dengan cara dilakukan pengikisan permukan daun menggunakan pisau steril, kemudian dipotong dengan ukuran $\pm 1 \times 1 \mathrm{~cm}$. Masing-masing potongan sampel diletakkan pada permukaan medium PDAC (Potato Dextrose Agar Chloramphenicol) yang telah memadat dengan posisi bagian jaringan daun menempel pada medium, dalam satu cawan petri berisi 3 potongan sampel. Diinkubasi selama 7-14 hari pada suhu $25{ }^{\circ} \mathrm{C}$.

\section{b. Pemurnian Jamur Endofit}

Pemurnian dilakukan untuk memisahkan koloni jamur endofit hingga diperoleh isolat jamur endofit. Koloni jamur yang tumbuh di sekeliling sampel daun beluntas dimurnikan berdasarkan morfologi makroskopik yang dapat diamati dari warna serta pertumbuhan koloni jamur. Diambil jamur endofit menggunakan ose, kemudian diinokulasikan dalam medium PDAC. Diinkubasi selama 5-7 hari pada suhu 25 ${ }^{\circ} \mathrm{C}$, jika pada saat pengamatan ditemukan pertumbuhan koloni yang berbeda secara makroskopis maka dipisahkan kembali hingga diperoleh isolat murni.

c. Karakterisasi Isolat Jamur Endofit
Karakterisasi isolat jamur endofit dengan melakukan pengamatan ciri-ciri makroskopik dan mikroskopik. Karakterisasi secara makroskopik ini dilakukan dengan pengamatan isolat jamur endofit yang telah murni meliputi warna koloni, warna sebalik koloni, bentuk atas, elevasi, tepi dan diameter koloni. Karakterisasi secara mikroskopik ini dilakukan pengamatan menggunakan preparat isolat jamur endofit melalui mikroskop. Terdapat dua jenis metode mikroskopik yaitu metode mikroskopik langsung. Metode mikroskopik langsung dilakukan dengan meneteskan methylen blue yang telah diinokulasikan isolat jamur endofit dan diamati menggunakan mikroskop. Sedangkan metode mikroskopik tidak langsung dilakukan dengan cara diinokulasikan isolat jamur endofit di atas medium PDA yang ada di object glass dan dibuat dalam kondisi lembab dengan gliserin yang ditetesi pada kertas saring sebagai pelapis cawan petri, kemudian diinkubasi selama 3-5 hari pada suhu $25{ }^{\circ} \mathrm{C}$, selanjutnya diamati menggunakan mikroskop.

\section{HASIL DAN PEMBAHASAN}

a. Isolasi Jamur Endofit

Isolasi jamur endofit dari tanaman yang berbeda ataupun dari bagian tanaman yang berbeda tetapi dari satu tumbuhan inang memiliki jenis isolat jamur yang berbeda. Isolasi jamur endofit terlebih dahulu dilakukan sterilisasi permukaan sampel sebelum ditanamkan dalam medium. Sterilisasi permukaan sampel dilakukan dengan cara merendam sampel dalam alkohol 70\%, kemudian 
$\mathrm{NaOCl} 5,25 \%$ dan terakhir direndam kembali dalam alkohol 70\%. Proses sterilisasi permukaan untuk dapat menjamin sterilitas permukaan sampel dari kontaminasi organisme. Sampel yang telah disterilisasi permukaanya kemudian dibuka jaringan daun dan ditempelkan pada medium yang telah memadat. Medium yang digunakan saat isolasi yaitu medium PDA yang ditambahkan dengan kloramfenikol (PDAC), hal ini dilakukan untuk menekan pertumbuhan bakteri yang kemungkinan ikut tumbuh saat isolasi. Hasil dari isolasi jamur endofit pada ketiga replikasi setelah dilakukan pengamatan selama 2 minggu dapat dilihat pada Gambar 1.

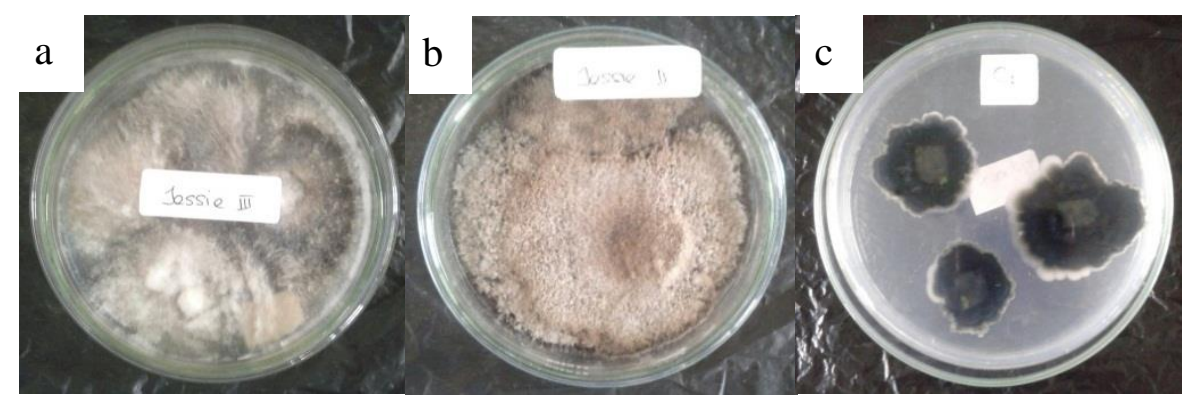

Gambar 1. Jamur Endofit dari daun beluntas (Pluchea indica (L.) Less.) setelah inkubasi selama 2 minggu, (a) Replikasi pertama, (b) Replikasi kedua, (c) Replikasi ketiga.

Jamur endofit yang tumbuh di sekeliling daun beluntas dimurnikan hingga memperoleh isolat jamur endofit. Pemisahan ini berdasarkan warna dan pola pertumbuhan koloni jamur dan ditumbuhkan kembali dalam medium PDAC yang baru. Berdasarkan Gambar 1, hasil isolasi pada replikasi pertama secara makroskopik dalam satu cawan terlihat jamur yang tumbuh pada masingmasing daun memiliki warna dan pola pertumbuhan yang berbeda. Jamur yang akan diisolasi yaitu jamur dengan koloni berwarna putih, hal ini dikarenakan jamur yang tumbuh di sekeliling daun lainnya sama seperti jamur pada replikasi kedua yaitu berwarna hitam. Pada replikasi kedua dan ketiga berdasarkan pengamatan secara makroskopik dalam satu cawan hanya terdapat satu jenis jamur endofit yang tumbuh dalam satu cawan. Jamur endofit yang tumbuh pada replikasi kedua dan ketiga memiliki warna yang sama yaitu berwarna hitam, tetapi memiliki pola pertumbuhan yang berbeda sehingga dapat disimpulkan bahwa jamur endofit yang tumbuh pada replikasi kedua dan replikasi ketiga berbeda.

\section{b. Karakterisasi Isolat Jamur Endofit} Isolat jamur endofit dari daun beluntas yang telah murni selanjutnya dikarakterisasi untuk melihat ciri-ciri jamur secara makroskopik dan mikroskopik. Hasil isolasi jamur endofit dari daun beluntas dapat dilihat pada Gambar 2. 

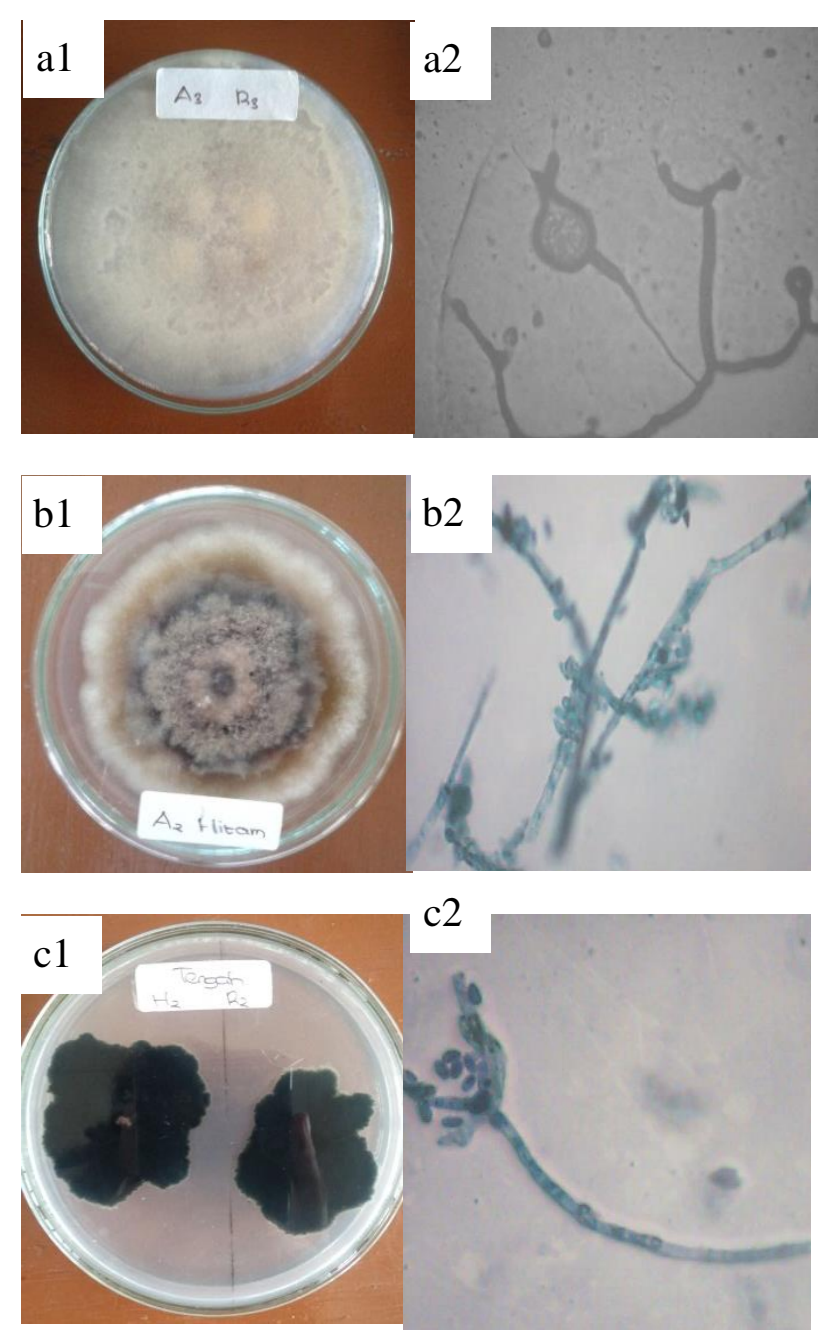

Gambar 2. Isolat Jamur Endofit daun beluntas (Pluchea indica (L.) Less.). Diperoleh tigas isolat jamur endofit, yaitu (a1) Isolat Jamur Endofit Putih, (a2) hasil pengamatan Mikroskopik Isolat Jamur Endofit Putih, (b1) Isolat Jamur Endofit Hitam 1, (b2) hasil Pengamatan Mikroskopik Isolat Jamur Endofit Hitam 1, (c1) Isolat Jamur Endofit Hitam 2, dan (c2) hasil Pengamatan Mikroskopik Isolat Jamur Endofit Hitam 2.

Berdasarkan Gambar 2 dapat dilihat hasil isolasi jamur endofit dari daun beluntas (Pluchea indica (L.) Less.) diperoleh tiga isolat jamur endofit yaitu isolat jamur endofit putih, isolat jamur endofit hitam 1 dan isolat jamur endofit hitam 2. Pengamatan makroskopik pada isolat jamur endofit putih yang tumbuh pada medium PDA koloni berwarna putih seperti kapas dan sebalik koloni juga berwarna putih. Dilihat dari atas berbentuk bulat, elevasi halus dan dengan tepi koloni timbul. Hari ketiga setelah inokulasi diameter koloni mencapai 1,8 $\mathrm{cm}$ dan diameter koloni dapat mencapai 5 $\mathrm{cm}$ pada hari ketujuh. Hasil pengamatan mikroskopik isolat jamur endofit putih memiliki hifa aseptat dan hialin, hifa berbentuk stolon, sporangiospora, sporangium dan sporangiofor. Pada isolat jamur endofit hitam 1 yang tumbuh pada medium PDA koloni awalnya berwarna putih, lama-kelamaan bagian dasar koloni warna berubah menjadi hitam dengan ujung konidia berwarna putih dan sebalik koloni berwarna hitam. Dilihat dari atas 
bentuk konsentrik, elevasi lebat dan dengan tepi tumbuh ke dalam media. Hari ketiga setelah inokulasi diameter koloni mencapai $3,4 \mathrm{~cm}$ dan diameter koloni dapat mencapai $6 \mathrm{~cm}$ pada hari ketujuh. Hasil pengamatan mikroskopik isolat jamur endofit hitam 1 memiliki hifa yang berseptat dan hialin, bentuk hifa rhizoid, dan memiliki konidiospora yang berbentuk bulat.Pada isolat jamur endofit hitam 2 yang tumbuh pada medium PDA koloni berwarna hitam dan sebalik koloni juga berwarna hitam. Dilihat dari atas bentuk menyebar tidak teratur, elevasi halus dan dengan tepi timbul. Hari ketiga setelah inokulasi diameter koloni mencapai $1,5 \mathrm{~cm}$ dan diameter koloni dapat mencapai $3 \mathrm{~cm}$ pada hari ketujuh. Hasil pengamatan mikroskopik isolat jamur endofit hitam 2 memiliki hifa aseptat dan hialin, hifa berbentuk rhizoid, dan memiliki konidiospora dengan bentuk elips.

\section{KESIMPULAN}

Hasil isolasi jamur endofit dari daun beluntas (Pluchea indica (L.) Less.) diperoleh tiga isolat jamur endofit yaitu isolat jamur endofit putih, isolat jamur endofit hitam 1 dan isolat jamur endofit hitam 2.

\section{DAFTAR PUSTAKA}

1. Ardiansyah. 2003.Aktivitas Antimikroba Ektrak Daun Beluntas (Pluchea indica L.) dan Stabilitas Aktivitasnya Pada Berbagai Konsentrasi Garam dan Tingkat pH. Jurnal Teknol dan Industri Pangan. XIV.(2). 90-97.

2. Strobel, G. A., and B. Daisy. 2003. Bioprospecting for Microbial Endhophytes and Their Natural Products. Microbiology and Molecular Biology Review. 67. (4). 419-502.

3. Agusta, Andria. 2009. Biologi dan Kimia Jamur Endofit. ITB. Bandung.

4. Dalimartha, Setiawan. 1999. Atlas Tumbuhan Obat Indonesia Jilid I. Trubus Agriwidya. Jakarta.

5. Sugijanto, N. E., G. Indrayanto, N. C. Zaini. 2004. Isolasi dan Determinasi Berbagai Jamur Endofit dari Tanaman Aglaia elliptica, Aglaia eusideroxylon, Aglaia odorata dan Aglaia odoratissima. Jurnal Penelitian Medika Eksakta.5. (2). 4960. 